\title{
Effect of nitrogen ion implantation on in vitro corrosion behaviour of $\mathrm{NiTi}^{(\cdot)}$
}

\author{
R. Barcos*, A. Conde**, J. J. de Damborenea** y J. A. Puértolas*
}

\begin{abstract}
In the last decade, different surface modifications have been developed to enhance the biocompatibility of NiTi shape memory alloys. The present paper deals with the influence of nitrogen ion implantation on corrosion behavior of $\mathrm{NiTi}$ in Hank's solution. Nitrogen implantation at $150 \mathrm{keV}$ with nominal doses ranged from $0.5 \times 10^{17}$ to $8 \times 10^{17}$ ion $\mathrm{cm}^{-2}$ were used. Mechanical surface characterization was carried out by nanohardness, corrosion mechanism evaluation by electrochemical polarization and impedance spectroscopy (EIS) tests and surface composition by XPS spectra. The results point out the benefit of the $\mathrm{N}$-implanted for corrosion resistance at a suitable dose $2 \times 10^{17} \mathrm{ion} \mathrm{cm}-2$ and an increase of the mechanical properties with the doses.
\end{abstract}

\section{Efecto de la implantación iónica de nitrógeno en el comportamiento frente a la corrosión in vitro del NiTi}

\begin{abstract}
Resumen
Durante la pasada década se han empleado diferentes técnicas de modificación superficial para mejorar la biocompatibilidad de la aleación de NiTi con memoria de forma. Este trabajo se centra en el estudio de la influencia del $\mathrm{N}$ implantado con una energía de $150 \mathrm{keV}$ y con dosis nominales comprendidas entre $0.5 \times 10^{17}$ to $8 \times 10^{17}$ ion $\mathrm{cm}^{-2}$, en el comportamiento frente a la corrosión del NiTi en solución de Hank. Se han realizado medidas de nanodurezas y de resistencia a la corrosión mediante curvas de polarización potencio-dinámicas y espectroscopía de impedancia electroquímica, así como los cambios en composición promovidos en la superficie se evaluaron mediante XPS. Los resultados de dichos ensayos revelaron una mejora en la resistencia a corrosión del comportamiento para las muestras implantadas con una dosis de $\mathrm{N}$ de $2 \times 10^{-17}$ ion $\cdot \mathrm{cm}^{-2}$ y un aumento de la nanodureza y de la rigidez superficial con la dosis implantada
\end{abstract}

Palabras clave NiTi; Corrosión; Implantación iónica; Nanodureza; Nitrógeno.

\section{INTRODUCTION}

Properties of the shape memory alloy $\mathrm{NiTi}$, such as one and two-way shape memory effect, superelasticity, anelasticity, constant unloading stresses have been proposed for various applications in different fields in industry. These mechanical properties, in combination with the biocompatibility allow the use of $\mathrm{NiTi}$ in different devices in medicine ${ }^{[1]}$. However, despite the excellent corrosion resistance, $\mathrm{Ti}$ and $\mathrm{Ni}$ ion release into the adjacent tissue in some biological environments might have detrimental effect. As a consequence a harmful local and systemic effect can occur for some patients. Many methods have been tested to improve the $\mathrm{TiO}_{2}$ oxide layer and other to modify the reactivity of surface, with different success $^{[2]}$. In the first via, several techniques include the oxygen introduction in the surface like thermal oxidation $^{[3]}$, hydrothermal method ${ }^{[4]}$, sol-gel deposition ${ }^{[5]}$, plasma source ion implantation ${ }^{[6]}$ or plasma immersion ion implantation ${ }^{[7}$ and 8$]$.

Among the several methods to mitigate the leaching of $\mathrm{Ni}$, one of the most widespread is the coated technology based on titanium nitride, TiN. This thin film have been grown by laser gas nitriding ${ }^{[9]}$, powder immersion reaction assisted coating $^{[10]}$ or magnetron sputtering ${ }^{[11]}$. However, all the above mentioned methods introduce discontinuity

(·) Trabajo recibido el día 3 de agosto de 2007 y aceptado en su forma final el día 1 de febrero de 2008.

* Department of Materials Science and Technology. Centro Politécnico Superior-ICMA, Universidad Zaragoza-CSIC, E-50018 Zaragoza. Spain.

** National Center of Metallurgical Research (CENIM/CSIC), E-28040 Madrid, Spain. 
EFFECT OF NITROGEN ION IMPLANTATION ON IN VITRO CORROSION BEHAVIOUR OF NITI EFECTO DE LA IMPLANTACIÓN IÓNICA DE NITRÓGENO EN EL COMPORTAMIENTO FRENTE A LA CORROSIÓN IN VITRO DEL NITI

in the properties as consequence of the interface between bulk and coating. Direct implantation of nitrogen ${ }^{[12]}$ or plasma immersion ion implantation $(\mathrm{PIII})^{[13 \text { and } 14]}$ have been used in the last years as a method to get a graded compositional change in the surface and a better adhesion behavior compared to coating technologies. In spite of these studies, several aspects are still controversial, like the influence of the nitrogen beam doses in corrosion resistance, the presence of nickel depletion or the chemical state of the surface after the ion implantation. Concerning to the first point, Arenas et al. ${ }^{[15]}$ pointed out the existence of an optimal doses of nitrogen implantation for enhancing the corrosion behaviour of the titanium in simulated body fluid. From the previous experience on titanium alloys, in this work the authors have evaluated the influence on mechanical and corrosion properties of $\mathrm{NiTi}$ alloys with biomedical interest, establishing the optimal dose to combine improvements in hardness and corrosion resistance.

\section{MATERIALS AND METHODS}

The equiatomic nickel-titanium alloy was received from Memory Metalle GmbH (Weil am Rhein, Germany) in plates of $1 \mathrm{~mm}$ thickness with an amount of trace elements less than $0.1 \mathrm{wt} \%$. The transition temperature between martensite « austenite is below the ambient temperature. In consequence, the alloy presents superelasticity at temperatures during the microhardness and corrosion test. Disk samples of $20 \mathrm{~mm}$ in diameter were cut by electrochemical process from the plate and mechanically polished with 600-1,200 SiC grits and with dispersions of diamond microparticles, with a final average roughness of $R_{a}=101 \pm 45 \mathrm{~nm}$, measured with a PLm2300 Optical Imaging Profiler from Sensofar-Tec (Spain).

Nitrogen implantation was performed using a Whickham Ion Beams Systems as ion generator. The acceleration voltage was $150 \mathrm{keV}$, with nitrogen dosages of $0.5,1,2,4$ and $8 \times 10^{17}$ ions $\mathrm{cm}^{-2}$, which will be designated in the text as I05, I1, I2, I4, I8 respectively and NI for as-received sample. Program PROFILE has been used to obtain the theoretical profiles of the ionic implantation by means of the standard and high doses code. The last method provides a more realistic profile with a depth region close to $125 \mathrm{~nm}$ for the highest doses. The amount of nitrogen implantation was ranged from $30 \%$ at the lowest doses to $45 \%$ at the highest ones.

Electrochemical studies were performed in Hank's solution (Table I) at $\mathrm{pH} 7.4$ prepared from chemically pure reagents and deionized water. In order to avoid crevice corrosion an appropriate tape was used to mask the $\mathrm{NiTi}$, allowing $1 \mathrm{~cm}^{2}$ of its surface to be in contact with solution. All electrochemical measurements were performed at room temperature.

Corrosion mechanisms were evaluated by electrochemical impedance spectroscopy (EIS) and electrochemical polarization curves using a conventional three-electrode cell containing $100 \mathrm{ml}$ of Hank's solution. A saturated calomel electrode was used as the reference electrode, and $1 \mathrm{~cm}^{2}$ of implanted and non implanted $\mathrm{NiTi}$ as working electrode with a platinum counter electrode. Unimplanted specimens were mechanically polished before testing. The polarization curves were performed after $30 \mathrm{~min}$ of stabilization of the open circuit corrosion potential, while the impedance measurements were carried out up to $96 \mathrm{~h}$ of testing in the experimental solution. Both tests were performed at different locations of the specimens.

The electrodes were connected to a Radiometer Copenhagen PGP201 potentiostat. After stabilization of the corrosion potential (potential variation lower than $2 \mathrm{mV} / \mathrm{min}$ ) a cathodic potential step was applied to leave the samples at $-1000 \mathrm{mVvs}$. SCE. Then, potentiodynamic polarisation curves were performed in the anodic direction at a sweep rate of $0.3 \mathrm{mV} / \mathrm{s}$.

Impedance data were obtained through a computer controlled frequency response analyser Solartron SI-1255 and electrochemical interface Solartron SI-1287. A $10 \mathrm{mV}$ (rms) sinusoidal potential was applied, with a frequency sweep from $20 \mathrm{kHz}$ to $10 \mathrm{mHz}$.

Nanohardness measurements were performed using a Fischerscope ${ }^{\circledR}$ H100VP-XP PROG testing system, from Fischer Instrumentation Ltd. By

Table I. Electrolyte composition of Hanks' solution $(\mathrm{pH}=7.4)$

Tabla I. Composición química de la solución de Hank $(\mathrm{pH}=7,4)$

\begin{tabular}{|c|c|c|c|c|c|c|c|c|c|}
\hline Compound & $\mathrm{CaCl}_{2}$ & $\mathrm{Mg} \mathrm{SO}_{4} 7 \mathrm{H}_{2} \mathrm{O}$ & $\mathrm{KH}_{2} \mathrm{PO}_{4}$ & $\mathrm{NaCl}$ & $\mathrm{Na}_{2} \mathrm{HPO}_{4}$ & d-Glucose & Phenol Red. Na & $\mathrm{NaHCO}_{3}$ & $\mathrm{KCl}$ \\
\hline Concentration $\left(\mathrm{gl}^{-1}\right)$ & 0.140 & 0.148 & 0.06 & 8.0 & 0.048 & 1.0 & 0.011 & 0.35 & 0.4 \\
\hline
\end{tabular}


progressively increasing the applied load from 2 to $100 \mathrm{mN}$, this technique allows the determination of hardness depth profile. The hardness values have been determined from characteristic load-displacement curves according to DIN-50359.

XPS spectra were acquired with a VG-CLAM analyser in a high vacuum using a magnesium anode $((\mathrm{K} \alpha 1253.6 \mathrm{eV})$, working at $15 \mathrm{kV}, 20 \mathrm{~mA}$ and using an argon ion acceleration of $5 \mathrm{KeV}$. The direction of the photoelectron detection angle was 90 with the specimens. Broad scan spectra were made using an energy step of $150 \mathrm{eV}$, while narrow scans were performed of $\mathrm{C} 1 \mathrm{~s}$, Ti 2p, N 1s, Ni 2p and O 1s were determined using a scanning step size of $20 \mathrm{eV}$. All XPS spectra have been referenced to the $\mathrm{C} 1 \mathrm{~s}$ line of the hydrocarbon-type carbon $(284.8 \mathrm{eV})$.

\section{RESULTS AND DISCUSSION}

Nanohardness depth profiles in all the implanted samples are depicted in figure 1 . The as-received sample, NI, exhibits practically a constant value close to $2.5 \mathrm{GPa}$. The surface modification introduced by nitrogen ion implantation induces mechanical changes, since the hardness profile of the treated surfaces indicates higher hardness than the substrate beneath. However, the influence of the doses is low, with a smooth increase of the hardness surface when the dose increases. In addition, the hardness profile of these treated samples shows a maximum in a subsurface region around $25 \mathrm{~nm}$ in depth, especially

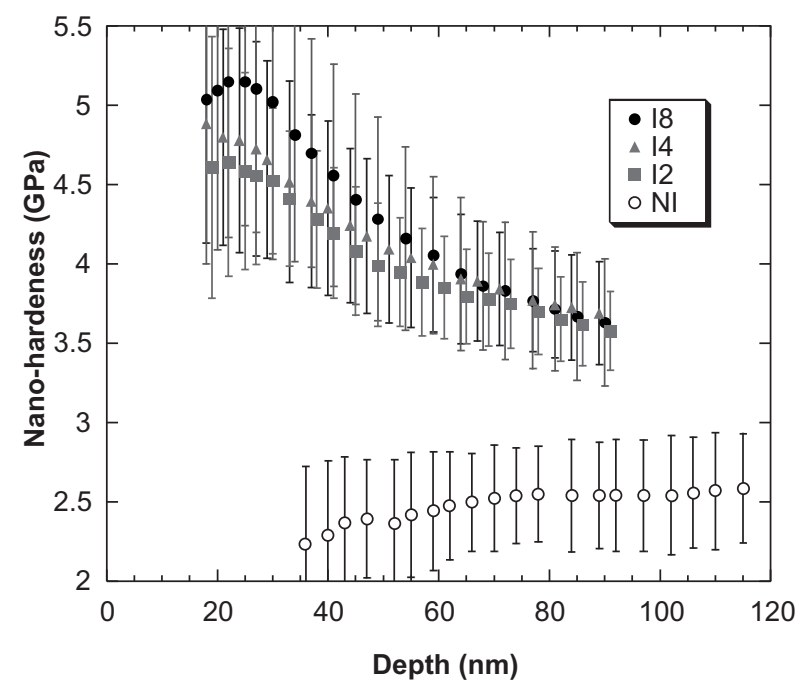

Figure 1. Nanohardness in function of the depth for $\mathrm{NI}, \mathrm{I2}, \mathrm{I} 4$ and 18 samples.

Figura 1. Perfil de nanodureza de las muestras NI, I2, 14 e 18. patent in I8 sample. Although in these implanted samples, the measurements do not reflect the full region affected by the implanted $\mathrm{N}^{+}$, since the applied load is not too high, at least a modify layer of 90 $\mathrm{nm}$ is observed. On the other hand, the Young's modulus in the non implanted sample, deduced from the load-indentation curves, is ranged in $58-65 \mathrm{GPa}$ and the stiffness of the layer surface increases after ion implantation up to values ranging in 68-72 GPa.

The values of hardness and stiffness found in $\mathrm{NiTi}$ samples before the modification surface are similar to de values of hardness and Young modulus reported for the same NiTi substrate by Cheng et al. ${ }^{[7]} 3.5 \mathrm{GPa}$ and $85.6 \mathrm{GPa}^{[7]}$ and Poon et al. ${ }^{[13]}, 4 \mathrm{GPa}$ and 55-60 $\mathrm{GPa}$, respectively.

The first effect caused by the $\mathrm{N}^{+}$ion implantation is the increase of these magnitudes. So, the hardness of the sample subjected at the maximum doses achieves values close to $5.1 \mathrm{GPa}$ in our measurements, which are also consistent with the average value of hardness in the affected region of $\mathrm{NiTi}$ samples treated by nitrogen PIII on the same NiTi alloy at a dose of $9.6 \cdot 1^{16}$ ions $\mathrm{cm}^{-2}[13]$. These results are in agreement with others reported in the literature, in which and in general, high dose ion implantations of nitrogen on different alloys seem to improve the mechanical and tribological properties of the surface ${ }^{[16-18]}$.

Although the effect of ion implantation doses is always positive regarding the mechanical features, the influence of the doses is critical in corrosion resistance.

Polarization curves of NiTi alloys in Hank's solution revealed a similar shape for both unimplanted and implanted specimens. The polarisation curves depicted in figure 2 showed that none of the

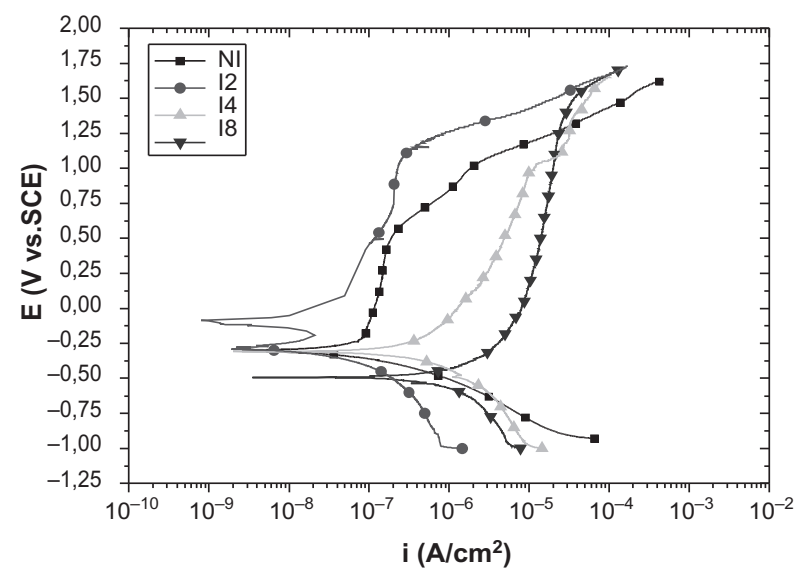

Figure 2. Polarization curves for $\mathrm{NI}, \mathrm{I} 2, \mathrm{I} 4$ and 18 specimens.

Figura 2. Curvas de polarización de las muestras $\mathrm{NI}, 12$ e 18. 
tested materials exhibit the traditional active-passive transition because they are in a passive state prior to be tested. In the same line, they do not exhibit a breakdown potential or pitting potential in the range of potentials sweep. In fact the abrupt increase of current density when reaching $1 \mathrm{~V}$ vs.SCE has to be attributed to oxygen evolution. Therefore, all $\mathrm{NiTi}$ samples are passive and no evidence of pitting has been found in any condition.

In spite of the similarity in the polarization curves, some differences appear in the corrosion potentials and passive current densities (Figure 2). Non implanted specimens showed a current density of $4 \cdot 10^{-8} \mathrm{Acm}^{-2}$. Similar values were reported by Cissé et al. ${ }^{[19]}$ on mechanically polished $\mathrm{NiTi}$. On the other hand, it has been appreciated that at the highest doses $\left(4 \times 10^{17}\right.$ and $8 \times 10^{17}$ ions $\mathrm{cm}^{-2}$ ) the corrosion resistance decreases substantially, while at the lowest doses $\left(0,5,1 \times 10^{17}\right.$ and $2 \times 10^{17}$ ions $\left.\mathrm{cm}^{-2}\right)$ there is an improvement with respect to the un-implanted alloy. In fact, when the implanted dose is $\leq 2 \times 10^{17}$ ions $\mathrm{cm}^{-2}$ the current density found was about $5 \cdot 10^{-9}$ $\mathrm{Acm}^{-2}$, almost one order of magnitude lower than that obtained for $\mathrm{NI}^{[20]}$. For this reason and in order to clarify the presentation of the data, hereinafter only samples in the range from $2-8 \times 10^{17}$ ions $\mathrm{cm}^{-2}$ were studied, i.e., referred hereafter as I2, I4 and I8 samples.

It is also interesting to note that the corrosion potential defined by the polarisation curves for NI and I2 sample are the same (around $-275 \mathrm{mV}$ vs. SCE). Althought, the implanted specimen depicted another pseudo-corrosion potential at $-85 \mathrm{mV}$ vs. SCE. This peak would indicate an activation state in which the surface is being oxidized and consequently a film is formed on the NiTi surface promoting its passivation. On the contrary, higher doses provoked appreciable decreases in the corrosion resistance of the NiTi alloy $\left(3 \cdot 10^{-7}\right.$ and $2 \cdot 10^{-6} \mathrm{Acm}^{-2}$ for I4 and I8, respectively) as well as a corrosion potential more active for the implanted specimens with highest dose ( $-435 \mathrm{mV}$ vs. SCE).

The reason for this behaviour could be that the high energy beam together to high doses during ionic implantation could induce damage on the $\mathrm{NiTi}$ surface. Due to the high density flux, the surface could become more chemically active (crystalline damage) leading to lowered corrosion resistance ${ }^{[15]}$. The authors observed this effect working with lower nitrogen ions of energy, $25 \mathrm{keV}$, pointing that the optimum dose from corrosion viewpoint is about $3 \cdot 10^{17}$ ions $\mathrm{cm}^{-2}$. In this work none of the doses studied lead to significant improvements, suggesting that higher energies of implantation can produce a deleterious effect instead of an improvement on the corrosion resistance properties. In this sense Sharkeev et al. ${ }^{[21]}$ reported that doses higher than 3 x $10^{17}$ ions $\mathrm{cm}^{-2}$ (implanted at energy of $90 \mathrm{keV}$ ) could lead to a softening of the surface.

Electrochemical impedance spectroscopy has also been used to characterise the NiTi surface after implantation. Figure 3 shows the impedance spectra for NI and I2-I8 specimens after 3 hours of immersion in Hank's solution. As it can be seen, I2 exhibits a pure capacitive response which is characterised by phase angle about $90^{\circ}$ at whole frequency range. A time constant is observed in Bode plots. Moreover, the value of the impedance modulus at low frequencies, $10 \mathrm{mHz}$, is about $10^{6} \Omega \mathrm{cm}^{2}$. On the other hand, NI and I8 reveal a resistive behaviour with lower values for $/\left.\mathrm{Z}\right|_{10 \mathrm{mHz}}$, than for I2 implanted specimen. Finally, the specimen implanted with a intermediate doses, I4 plots two time constant revealing the presence of a diffusion tail at lower frequencies. Therefore, the results from the EIS impedance are consistent with those obtained from DC current and as well as it was shown the specimen implanted with the lowest doses improved the corrosion resistance nearly by one order of magnitude regarding the NI, whilst the implantation with medium and highest doses are detrimental from corrosion point of view.

Nevertheless, at longer immersion times, $96 \mathrm{~h}$, some changes are observed for NI, I4 and I8. While the spectra for I2, hardly evolves with immersion time, the specimens that initially had worst corrosion resistance improved their corrosion resistance as consequence of a thickening of the titanium oxide layer. In figure 4 are plotted the impedance spectra corresponding to I4 (as representative behaviour of medium-high dose implanted specimens) compared with NI, after 96 hours of immersion. After 96 hours, all the specimens plot the same values for $/ \mathrm{Z} / 10 \mathrm{mHz}$, about $5 \cdot 10^{6} \Omega \cdot \mathrm{cm}^{2}$. This result is quite remarkable because it reveals that nitrogen implantation with the optimal dose allows to reach an excellent corrosion resistance slowing down the growth of titanium oxides and avoiding the risks derived from its growth in excess.

In spite of the chemical activity induced by ion implantation suggested, other authors assume that other possible reasons for such loss los corrosion resistance could be the presence of new compounds in the surface, which might alters the passivation layer of $\mathrm{TiO}_{2}$. In order to explain these assessment XPS spectra were performed.

The high resolution spectra of titanium, oxygen and nitrogen corresponding to I2, I4 and I8 specimens are plotted in figure $5 \mathrm{a}, 5 \mathrm{~b}$ and $5 \mathrm{c}$, respectively. Additionally, the binding energies obtained after the fitting process of each element are gathered in tables 

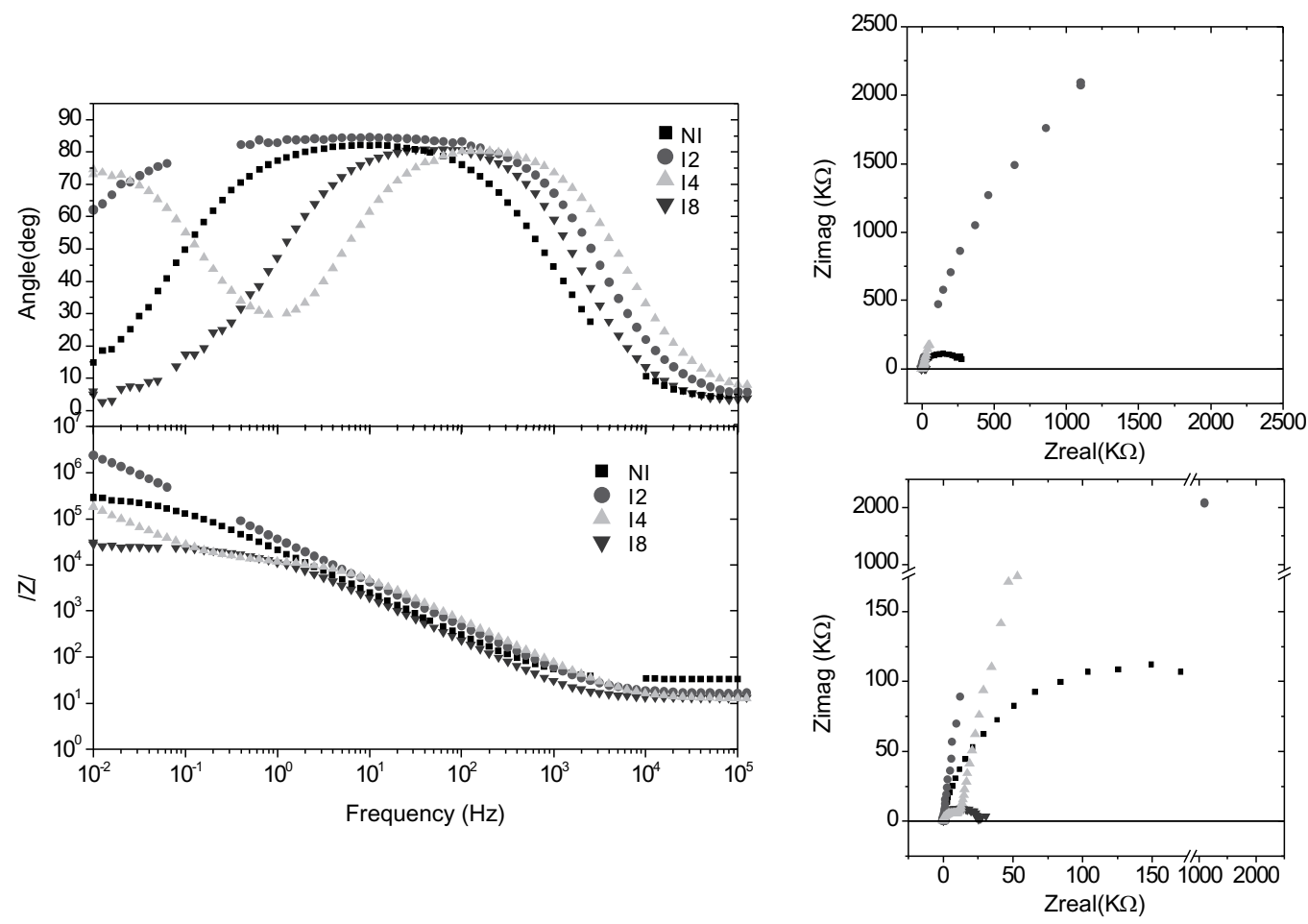

Figure 3. Impedance measurements after three h in Hank's solution for $\mathrm{NI}, 12$, 14 ,and 18.

Figura 3. Espectros de impedancia de las muestras NI, 12, 14 e 18 tras 3 h de inmersión en solución de Hank.
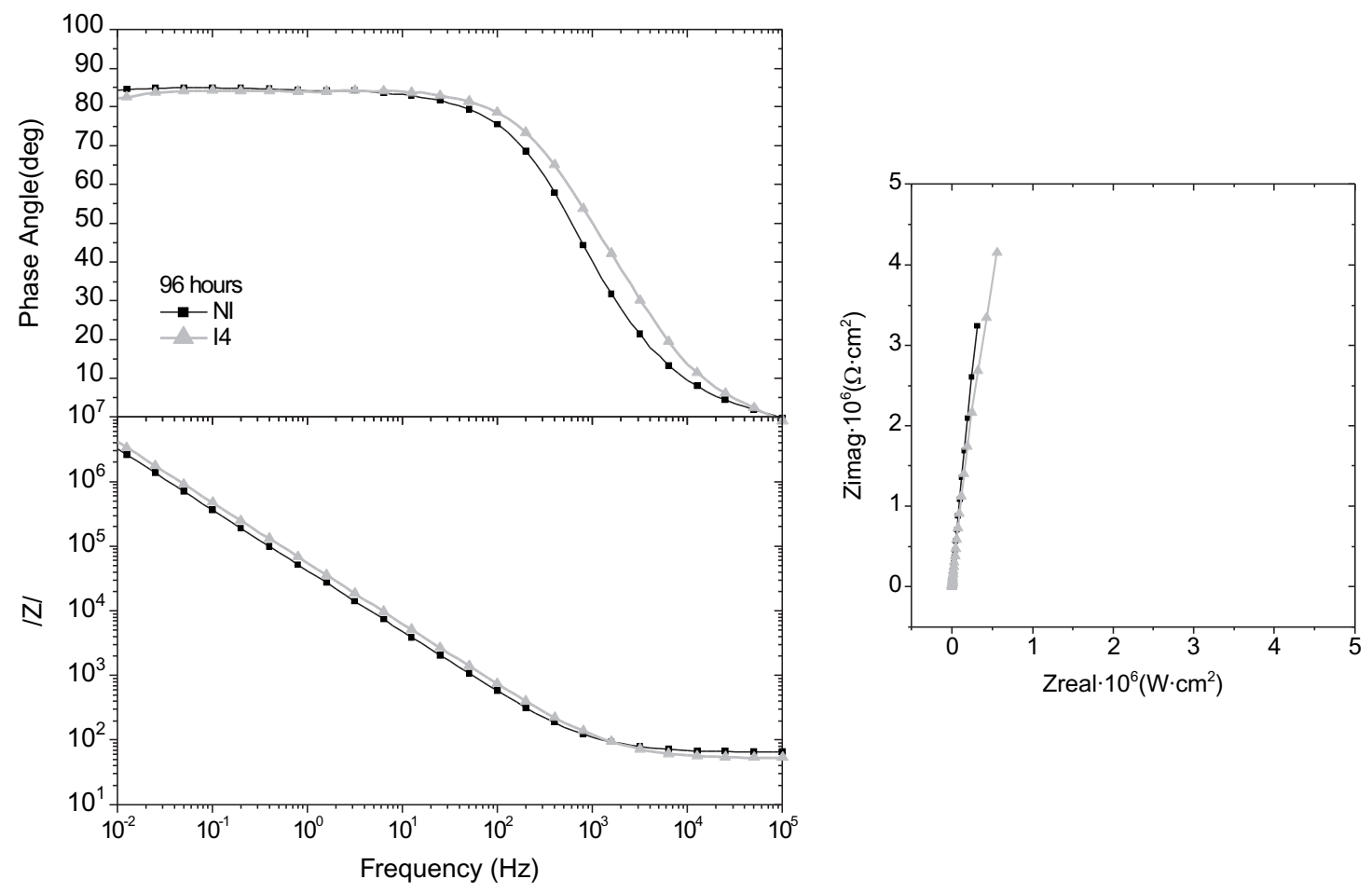

Figure 4. Comparison of impedance spectra for NI, 14 after $96 \mathrm{~h}$ in Hank's solution.

Figure 4. Comparación de los espectros de impedancia de NI, e 14 tras 96 h de inmersión en solución de Hank. 
EFFECT OF NITROGEN ION IMPLANTATION ON IN VITRO CORROSION BEHAVIOUR OF NITI EFECTO DE LA IMPLANTACIÓN IÓNICA DE NITRÓGENO EN EL COMPORTAMIENTO FRENTE A LA CORROSIÓN IN VITRO DEL NITI

a)

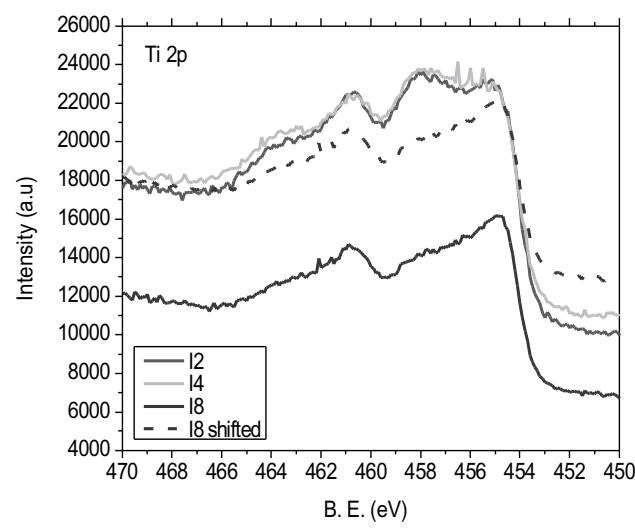

b)

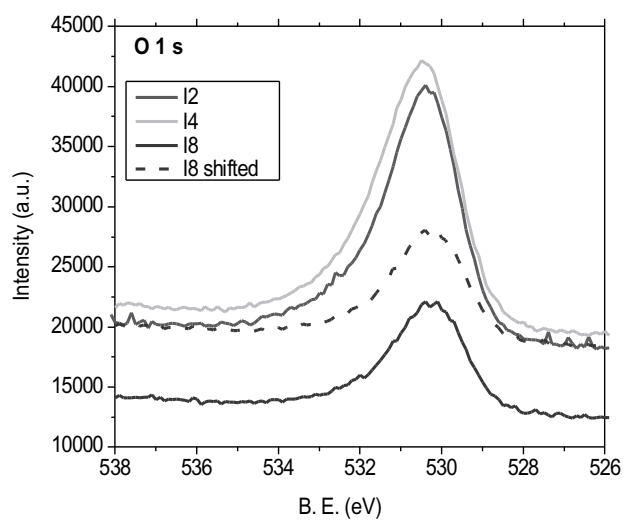

c)

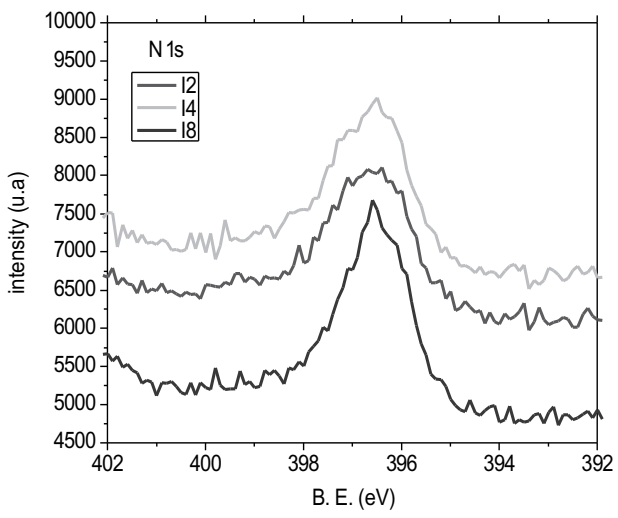

Figure 5. XPS spectra of a) Ti 2p, b) O 1s and c) $\mathrm{N}$ 1s for 12 , 14 and 18 samples.

Figura 5. Espectro de XPS. a) Ti 2p, b) O 1s y c) N 1s, para las muestras 12, 14 e 18.

Table II. Oxygen spectra for I2, 14 and I8 specimens

Tabla II. Espectro del oxígeno correspondiente a las muestras 12, 14 e 18

\begin{tabular}{ccccc}
\hline O 1s & $\mathbf{1 2}$ & $\mathbf{1 4}$ & $\mathbf{1 8}$ & Chemical Bond \\
\hline $\mathrm{O}_{1}(\mathrm{eV})$ & 530.3 & 530.8 & 530.5 & $\mathrm{TiO}_{2}\left(\mathrm{Ti}^{4+}\right)$ \\
$\mathrm{O}_{2}(\mathrm{eV})$ & 531.3 & 532.0 & 531.5 & $\mathrm{Ti}-\mathrm{O}$ \\
\hline
\end{tabular}

Table III. Titanium spectra for I2, 14 and I8 specimens

Tabla III. Espectro del titanio correspondientes a las muestras I2, I4 e I8

\begin{tabular}{cccccc}
\hline Ti 2 p (10min) & I2 & 14 & I8 & Chemical Bond & Theoretical B.E. \\
\hline $\mathrm{Ti}_{1}(\mathrm{eV})$ & 455.2 & 455.2 & 455.0 & $\mathrm{TiN}$ & $455.0\left(2 \mathrm{p}^{3 / 2}\right)$ \\
$\mathrm{Ti}_{2}(\mathrm{eV})$ & 456.6 & 456.7 & 456.5 & $\mathrm{Ti}-\mathrm{O}-\mathrm{N}$ & 456.3 \\
$\mathrm{Ti}_{3}(\mathrm{eV})$ & 458.4 & 458.4 & 458.4 & $\mathrm{TiO}_{2}$ & $458.7\left(2 \mathrm{p}^{3 / 2}\right)$ \\
$\mathrm{Ti}_{4}(\mathrm{eV})$ & 461.2 & 461.1 & 460.9 & $\mathrm{TiN}^{2}$ & $461.0\left(2 \mathrm{p}^{1 / 2}\right)$ \\
$\mathrm{Ti}_{5}(\mathrm{eV})$ & 463.7 & 463.9 & 462.9 & $\mathrm{TiO}_{2}$ & $464.0\left(2 \mathrm{p}^{1 / 2}\right)$ \\
\hline
\end{tabular}


Table IV. Nitrogen spectra for I2, 14 and 18 specimens

Tabla IV. Espectro de nitrógeno correspondiente a las muestras 12, 14 e I8

\begin{tabular}{cccccc}
\hline $\mathbf{N} 1 \mathbf{s}$ & $\mathbf{1 2}$ & $\mathbf{1 4}$ & $\mathbf{1 8}$ & Chemical bond & Theoretical B.E. \\
\hline $\mathrm{N}_{1}(\mathrm{eV})$ & 396.6 & 396.9 & 396.8 & $\mathrm{TiN}$ & 396.7 \\
$\mathrm{~N}_{2}(\mathrm{eV})$ & 398.7 & 398.3 & 397.4 & Ti-O-N & 398.1 \\
\hline
\end{tabular}

II- IV for any evaluated samples. From high resolution windows of each element, it is observed that the for all doses, the surface is composed of titanium oxides and titanium nitrides

Profile concentrations of each element, O 1s, C 1 s, Ti $2 p, N$ s and Ni $2 p$, in function of the sputtering time is plotted in figure 6 . It reveals that for all the sputtering times $\mathrm{N}$ content is higher than $\mathrm{Ni}$, suggesting the presence of an outer TiN layer. One of the main results is concerning to the Ni content (Fig. 7), which is notably reaching after 10 minutes a concentration of $\mathrm{Ni}$ which remains practically constant up to 20 minutes of sputtering.

The analysis revealed that NiTi specimens implanted with different doses of $\mathrm{N}^{+}$are mainly composed of titanium nitride, $\mathrm{TiN}$, and rutile, $\mathrm{TiO}_{2}$, together with some titanium oxynitrides and non stoichiometric oxides appeared as result of the changes induced by the sputtering with argon. Titanium oxides are placed in outer layers whereas TiN is placed underneath, since oxygen concentration decreases with the sputtering time as well as nitrogen concentration increases, figure 6 .

Concerning to the Ni composition, the XPS spectra point out the strong variation of the nickel with the time of sputtering, since at time a less than 2 minutes the concentrations practically are negligible. Similar trend were described by Wever et al. ${ }^{[22]}$ who observed that $\mathrm{Ni}$ was hardly resolved in outer layers of implanted specimens. However, in their case the Ni content increased up to $25 \%$ at. after 10 minutes of sputtering with an argon ion a)

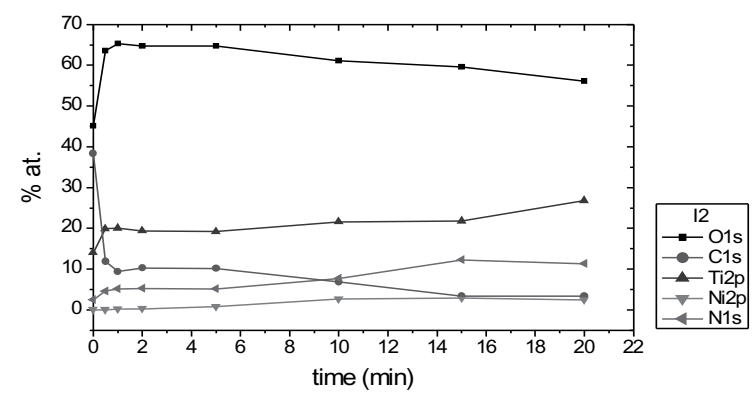

b)

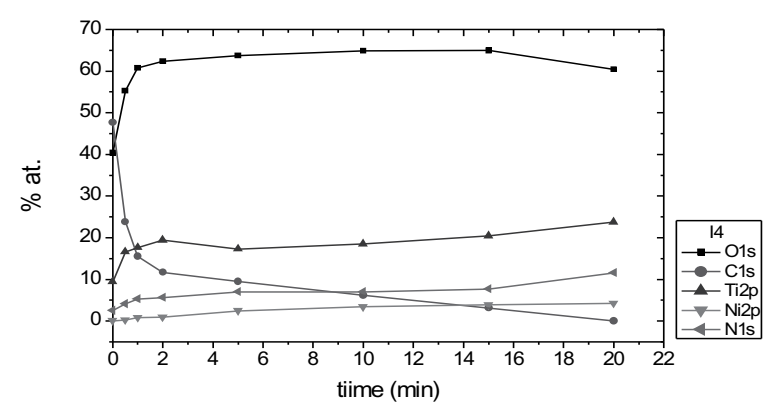

c)

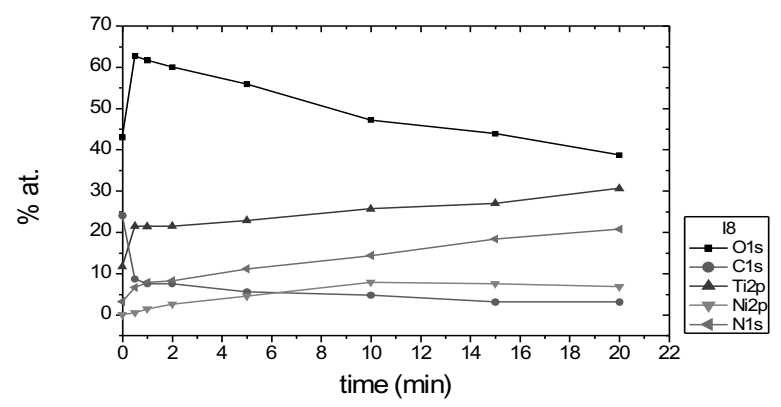

Figure 6. XPS Profile concentration of each element versus sputtering time for a) I2, b) 14 , and c) 18 .

Figura 6. Perfil de concentración de cada elemento correspondiente a las muestras a) 12, b) 14 y c) 18. 
EFFECT OF NITROGEN ION IMPLANTATION ON IN VITRO CORROSION BEHAVIOUR OF NITI EFECTO DE LA IMPLANTACIÓN IÓNICA DE NITRÓGENO EN EL COMPORTAMIENTO FRENTE A LA CORROSIÓN IN VITRO DEL NITI

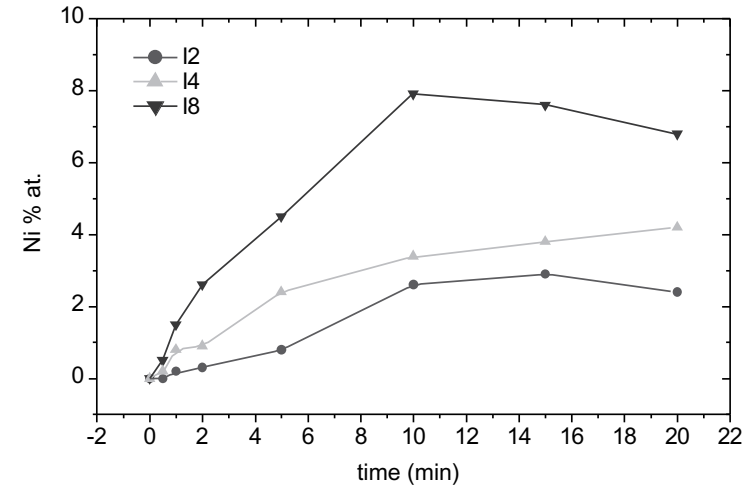

Figure 7. Ni concentration for I2, 14 and 18 samples versus sputtering time.

\section{Figura 7. Perfil de concentración de Ni corres-} pondiente a las muestras, 12,14 e 18.

acceleration about $10 \mathrm{KeV}$-double than used in this work-. Conversely, Ni contents as low as those described in this work were also sound by Z. D. Cui et al. ${ }^{[9]}$ for NiTi laser nitride specimens, where $\mathrm{Ni}$ contents about $2.5 \%$ at. were found after 30 minutes of sputtering. This behaviour seems to be a consequence of the preferential growth of a TiN layer rather than the less stable nickel nitride. The higher affinity of the nitrogen to titanium seems to be the cause of the nickel segregation, leading to the formation of $\mathrm{TiN}$ which chemical bond is stronger than $\mathrm{Ni}_{3} \mathrm{~N}{ }^{[13]}$.

On the other hand, the profile of Ni concentration depends on the $\mathrm{N}^{+}$dose used during the implantation (see Figure 7). The higher nitrogen dose, the higher $\mathrm{Ni}$ increase. This behaviour suggests that when the implantation is carried out with the highest dose, there is an additional effect of sputtering, removing the outer oxide layers and leaving the areas with higher nitrogen content and the alloy more exposed. This result agrees with the lower and higher content of oxygen and nitrogen, respectively, described in I8 sample with respect to the specimens implanted with lower doses. Whereas the oxygen atomic percentage ranges about $50-60 \%$ at for $\mathrm{I} 2$ and $\mathrm{I} 4$ specimens after $20 \mathrm{~min}$ of sputtering, it is about $38 \%$ at. for the sample I8, implanted with $8 \cdot 10^{17}$ ions $\mathrm{cm}^{-2}$. Similarly, nitrogen content is about $11 \%$ at. for the first two samples and about $20 \%$ at. for the specimen I8. As result of this, Ni content varies from 2.4 and $4.8 \%$ at. for samples treated at $2 \cdot 10^{17}$ ions $\mathrm{cm}^{-2}$ and $4 \cdot 10^{17}$ ions $\mathrm{cm}^{-2}$, respectively, while for the highest doses, $8 \cdot 10^{17}$ ions $\mathrm{cm}^{-2}$, the Ni content is $6.8 \%$.

This behaviour it is also clearly revealed by the titanium and oxygen spectra, figure 5 , where the intensity of the peaks of these two elements corresponding to the implanted samples are compared. It is clearly revealed that for the specimen treated with the highest $\mathrm{N}^{+}$dose, I8, the oxidised compounds decrease, revealing a lower content than those corresponding to specimens I2 and I4.

\section{CONCLUSIONS}

Nitrogen ion implantation induces improvements in nanohardness and Young modulus with the doses, while corrosion resistance improves just when the optimum dose is used. In this condition either DC or EIS, revealed improvements in corrosion properties about one order of magnitude with respect to unimplanted samples. These improvements rely on the presence of a stable outer titanium oxide layer in addition to TiN layer placed underneath. Conversely, higher doses turn the surface more chemically active as it is revealed by the increase of corrosion current density and the shift of the corrosion potential towards more cathodic values. This higher activity it is also revealed by the evolution of impedance measurements. Surfaces evolves reaching values of impedance as high as those initially described by the optimal dose implanted specimens, as consequences of the thickening of the oxide layer after 96 hours of test in Hank's solution.

\section{Acknowledgments}

Research funding by the Fondo de Investigaciones Sanitarias (FIS), Spain. Projects: PI031287, PI040364.

\section{REFERENCIAS}

[1] T. Duering, A. Pelton and D. Stockel, Mater. Sci. Eng. A-Struct. 273-275 (1999) 149-160.

[2] S.A. Shabalovskaya, Bio-Med. Mater. Eng. 12 (2002) 69-109.

[3] R.W.Y. Poon, J.P.Y. Ho, X.Y. Liu, C.Y. Chung, P.K. Chu, K.W.K. Yeung, W.W. Lu and K.M.C. Cheung, Mater. Sci. Eng A-Struct. 390 (2005) 444-451.

[4] F.T. Cheng, P. Dhi and H.C. Man, Surf. Coat. Technol. 187 (2004) 26-32.

[5] J.X. Liu, D.Z. Yang, F. Shi and Y.J. Cai, Thin Solid Films 429 (2003) 225-230.

[6] L. Tan, R.A. Dodd and W.c. Crone, Biomaterials 24 (2003) 3931-3939.

[7] Y. Cheng and Y.F. Zheng, Mat. Sci. Eng AStruct. 434 (2006) 99-104. 
[8] R.W.Y. Poon, J.P.Y. Ho, X. Liu, C.Y. Chung, P.K. Chu, K.W.K. Yeung, W.W. Lu and K.M.C. Cheung, Nucl. Instr. and Meth. in Phys. Res. B 237 (2005) 411-416.

[9] Z.D. CUI, H.C. MAN and X.J. YANG, Appl. Surf. Sci. 208-209 (2003) 388-393

[10] D. Starovsetsky and I. Gotman, Surf. Coat. Technol. 148 (2001) 268-276.

[11] Y.Q. Fu, H.J. Du and S. Zhang, Mater. Lett. 57 (2003) 2995-2999.

[12] H. Pelletier, D. Muller, P. Mille and J.J. Grob. Surf. Coat. Technol., 158-159 (2002) 301-308.

[13] W.Y. Poon, J.P.Y. Ho, X. Liu, C.Y. Chung, P.K. Chu, K.W.K. Yeung, W.W. Lu, K.M.C. Cheung, Thin Solid Films 488 (2005) 20-25.

[14] N. Shevchenko, M.T. Pham, M.F. Appl. Surf. Sci. 235 (2004) 126-131

[15] M.A. Arenas, T.J. Tate, A. Conde and J. de Damborenea, Br. Corros. J. 35 (2000) 232-236.
[16] O. Orturk, O. Onmus and D. L. Williamson, Surf. Coat. Technol. 196 (2005) 333-340.

[17] M. Soukieh, Radiat. Eff. Defect S 159 (2004) 73-79.

[18] G.S. Lakshmi and D. Arivuoli, Tribol. Int. 39 (2006) 548-552.

[19] O. Cissé, O. Savadogo, M. Wu and L. H. Yahia, J. Biomed. Mater. Res. A 61 (2002) 339-345.

[20] A. Conde, J. Pascual, J. de Damborenea and J.A. Puértolas. II Cong. Ibérico de Biomateriales, BIOÉvora, 2004

[21] Y.P. Sharkeev, S.J. Bull, A.J. Perry, M.L. Klingenberg, S.V. Fortuna, M. Michler, R.R. Manory and I.A. Shulepov, Surf. Coat. Technol. 201 (2006) 5915-5920

[22] D.J. Wever, A.G. Veldhuizen, J. de Vries, H.J. Busscher, D.R.A. Uges and J. R. van Horn. Biomaterials 19 (1998) 761-769. 